\title{
EXAMINING THE EFFECT OF ENTREPRENEURIAL LEADERSHIP ON ORGANIZATIONAL AGILITY THROUGH ORGANIZATIONAL LEARNING IN INDONESIAN SMES
}

\author{
Zulvia KHALID* and Panca Maulana FIRDAUS \\ Budi Luhur University, Indonesia \\ *zulvia.khalid@budiluhur.ac.id
}

\begin{abstract}
Tremendous change in environment during the Corona virus pandemic has put organizational agility as one of the most important discussion topics among scholars in the world. Small and Medium-sized Enterprises (SMEs) with limited resources, need to have strong agility to thrive in today's increasingly competitive market. It is, therefore, crucial to study the factors that may affect organizational agility. This study aims to examine the effects of entrepreneurial leadership on organizational agility through organizational learning in the perspective of organizational behavior. There was a scarcity of evidence on which entrepreneurial leadership could significantly influence organizational agility through organizational learning. The respondents are 200 employees who work at SMEs within the Small Industrial Village which is called Perkampungan Industri Kecil (PIK) in East Jakarta, Indonesia. Data were obtained through the survey method and quantitatively analyzed using SEM - LISREL 8.8. The results indicated that each entrepreneurial leadership and organizational learning has significantly affected organizational agility, and entrepreneurial leadership has significantly affected organizational learning. This study also found that organizational learning partially mediates the relationship between entrepreneurial leadership and organizational agility. These results provide recommendations for SMEs entrepreneurs to promote organizational learning in order to enhance the effect of entrepreneurial leadership to increase organizational agility.
\end{abstract}

\section{Keywords: Entrepreneurial Leadership, Organizational Learning, Organizational Agility}

\section{BACKGROUND}

In today's age of instability and ambiguity, changes occur in a disruptive and pervasive manner all over the world. Numerous changes take place in various forms of economic insecurity, volatile environment, changing market needs and tastes, the emergence of new technology and trends, as well as the advent of opportunities and unexpected obstacles (Steinberg, 2015). Those phenomena become much more dramatic because of the emergence of corona virus diseases 19 (COVID-19) which has been pandemically spreading in the society. It has not only affected global health but also caused economic slowdown (Ozili, 2020). Many businesses, including SMEs, suffered greatly during the recession. In Indonesia, for example, SMEs' sales revenue has fallen by $30 \%$ to $35 \%$ (Gorbiano \& Iswara, 2020). This condition makes it difficult to scale up their market and, in some cases, many SMEs struggle to survive.

Most problems faced by Indonesian SMEs' lie on the organizational knowledge, entrepreneurial and leadership skills (Irawan, 2020; Wilantara \& Susilawati, 2016). This condition is aggravated by the culture existing within the company where employees lack the awareness to develop their self-competence. It is shown in the workplace environment and culture, in which employees only follow a fixed output goal, trapped in a work routine schedule, and have little chances to learn and improve their expertise and skills. As a result, many SMEs have unskilled human resources with inadequate technological capabilities, weak entrepreneurial knowledge, and insufficient leadership skills (Khalid et al., 2020). These circumstances have put them at a competitive disadvantage (Yoshino \& Taghizadeh Hesary, 2016).

In order to thrive, SMEs need to have strong agility as a key weapon against larger and more powerful competitors (Triaa et al., 2016). However, developing organizational agility necessarily requires a complex strategy that is influenced by a variety of factors. Leadership and organizational learning among others, are considered as critical variables of organizational agility (Akkaya \& Celal, 2020; Melián-Alzola et al., 2020; Menon \& Suresh, 2020; Molodchik \& Jordan, 2016)one for adults, one paediatric and one neonatal. The unit of analysis was ICUs personnel (324 individuals: $14.5 \%, 48.8 \%$ and $36.7 \%$ from the categories of doctors, nurses and nurses' aides, respectively. A number of researchers have attempted to explore the association between organizational learning, leadership and organizational agility, but the majority of them were conducted in large institutions such as colleges, banks, hospitals, and other large corporations. There were relatively few studies addressed the effect of entrepreneurial leadership on organizational agility. To the utmost extent of the authors' insight, there is yet to be a research that investigates how organizational learning mediates the effects of entrepreneurial leadership on organizational agility in SMEs framework. Hence, this research attempts to fill the gaps of previous studies and is worthy of scholarly review.

\section{Entrepreneurial Leadership (EL) and Organizational Agility (OA)}

$\mathrm{OA}$ is a necessity for all companies around the globe in order to survive and stay relevant with today's hyper-competitive business environment (Anca-Loana, 2019; Wageeh, 2016). Although it is commonly debated in the literature, no single accurate concept of OA has been developed. Different authors and researchers have defined it from different points of views. OA refers to organization's capacity to rapidly recognize and capitalize on new market opportunities (Holotiuk et al., 2018; Setili, 
2014), the ability to adapt to changes in markets and the environment in a productive and cost-effective way (North \& Varvakis, 2016), the capacity of employees to improve the survival and growth the business environment (Saha et al., 2017). In this study, the authors define OA as the ability of the employees to adapt and respond to changes quickly and effectively in order to achieve competitive advantage.

The success of developing OA very much relies on the leadership. Effective leadership is regarded as a key element in creating OA (Gagel, 2018; E. G. K. and Prange, 2018). Effective leadership influences and directs the employees' behavior (Colquitt et al., 2017) towards the advancement of OA. In today's volatile market environment, effective leaders are required not only able to lead, but must also be a contributor and facilitator as an entrepreneur (Zainol et al., 2018). The idea of EL is becoming increasingly relevant as organizations need to be more entrepreneurial in order to improve their efficiency and potential for adaptation and long-term sustainability (Esmer \& Dayi, 2018; Renko, 2018). EL is the most effective leadership style in improving innovation and opportunity recognition(Garciá-Vidal et al., 2019; Raeymaekers, 2010). EL promotes and allows companies to embrace processes that strengthen the culture of corporate innovation by identifying and capitalizing on opportunities to enhance organizational success, address challenges creatively, and successfully and efficiently use the organization's resources (Sawaean \& Ali, 2020).

Although the relationship between EL and OA has not been extensively reviewed, some researchers have underlined the impact of leadership style in improving OA (Gagel, 2017; Lootah et al., 2020; Melián-Alzola et al., 202.0) It is then assumed that EL can also affect OA in SMEs. Therefore, H1: EL has positive effect on OA.

\section{Organizational Learning (OL) and Organizational Agility (OA)}

To create agile organizations, management must be aware that what should be agile is its employees, not the organization itself (Wendler, 2016)an organization does not only comprise development teams, and research often lacks an organizational perspective on agility. Presently, we have no consensus about what constitutes an \" agile organization \". Hence, in this study, I identify the structure behind the concept of organizational agility using an exploratory research approach. I conducted a survey among organizations in the software and IT service industry and performed an, exploratory factor analysis and a cluster analysis (based on the variables. For that reason, efforts to be agile should be more emphasis on developing the employees capacity, knowledge and skill (Muduli, 2016). For that reason, organizations must accommodate OL that occurs not only on an individual but also on an organizational level (Matthews et al., 2017)leading to sustained improvements over time in the context of smalland medium-sized enterprises (SMEs.
$\mathrm{OL}$ is very crucial for any organizations in order to adapt and thrive in this changing and challenging business environment and it is a core element of OA (Menon \& Suresh, 2020). Numerous concepts of OL have been established by different scholars. It is described as a process that develops new ways in which the organization sees or understands things (Chiva et al., 2014)[, the creation of observations, information, and interactions between past actions and the efficacy of future actions (Tatachari et al., 2014), and is characterized as a transition that happens in the organization as it gains experience (Annosi et al., 2020). In this study the authors define OL as a process of developing the knowledge and skill in organizations. It involves the process of knowledge acquisition, knowledge distribution, knowledge interpretation, and storage for future use in organizational memory [(Kasemsap, 2015; Schermerhorn, Jr. et al., 2010).

The role of $\mathrm{OL}$ is very crucial when organizations have to cope with unpredictable and confusing market conditions (Raeisi \& Amirnejad, 2017). Noruzy et al. clarify that $\mathrm{OL}$ will enable organizations to overcome today's challenges (Do \& Mai, 2020). It was described that effective OL could allow organizational participants to learn exactly what is required in order to collaborate and adjust their practice to the demands of achieving organizational goals and objectives (Langer, 2018). Several studies have proved that OL could significantly improve OA(Bahrami et al., 2016; Mashkani \& Khodadadi, 2016)absorbing, retaining, transferring, and application of knowledge within an organization. This article aims to examine the mediating role of organizational learning in the relationship of organizational intelligence and organizational agility. Methods This analytical and crosssectional study was conducted in 2015 at four teaching hospitals of Yazd city, Iran. A total of 370 administrative and medical staff contributed to the study. We used stratified-random method for sampling. Required data were gathered using three valid questionnaires including Alberkht (2003. It is assumed that OA could be developed by improving OL in Indonesian SMEs. Hence, the authors state the following hypothesis:

$\mathrm{H} 2$ : OL has positive effects on OA.

\section{Entrepreneurial Leadership (EL) and Organizational Learning (OL)}

OL will be effectively developed if the employees have strong motivation to learn things that are relevant to the organizational needs (Griffin \& Moorhead, 2014). Leaders should encourage and inspire the employees to learn constantly so that the anticipated capacity to develop OA can be fulfilled. Some scholars have highlighted the role of leadership on OL. A study in the health care sectors of Ardabil Social Security Organizations in Iran indicated that leadership styles and OL have strong correlations (Golmoradi \& Ardabili, 2016). A study in some enterprises in the UK (Megheirkouni, 2017) and in Taiwan (Liao et 
al., 2017) proved that transformational leadership has effect on OL. Based on the aforementioned studies, it is assumed that EL will also affect OL at Indonesian SMEs. Therefore, the authors state the following hypothesis:

H3: EL has positive effects on OL

\section{Organizational Learning (OL), Entrepreneurial Leadership (EL) and Organizational Agility (OA)}

A number of researchers have indicated that leadership has positive effects on OA (Gagel, 2017; Raeisi \& Amirnejad, 2017) and OL (Golmoradi \& Ardabili, 2016; Liao et al., 2017; Megheirkouni, 2017)the purpose of this paper is to propose a conceptual framework and the theoretical model in order to examine the influence of leadership, organizational learning (OL, OL also has positive effects on OA (Bahrami et al., 2016; Muduli, 2017)absorbing, retaining, transferring, and application of knowledge within an organization. This article aims to examine the mediating role of organizational learning in the relationship of organizational intelligence and organizational agility. Methods This analytical and crosssectional study was conducted in 2015 at four teaching hospitals of Yazd city, Iran. A total of 370 administrative and medical staff contributed to the study. We used stratified-random method for sampling. Required data were gathered using three valid questionnaires including Alberkht (2003. Based on the logic of syllogism, it is assumed that OL has mediation role in the relationship between EL and OA. Hence the authors develop the following hypothesis:

H4: EL has positive effects on OA mediated by OL.

\section{METHODS}

This study examines the effect of EL and OL on $\mathrm{OA}$, the direct effect of EL on OL and the mediating effects of OL in the relationship between EL and OA. The measurements of each variable were adapted from relevant researches and literatures. OA is measured using 5 indicators consisting of anticipatory behavior (ANTI), responsive behavior (RESP), adaptive behavior (ADAP), creativity (CREA), and resilience(RES) (Braun etal., 2017; Sharifi \& Zang, 2001; Sherehiy \& Karwowski, 2014; Triaa et al., 2016). EL is measured using 4 indicators consisting of proactiveness (PRO), innovativeness (INO), risk-taking (RISK), and decision making (DEC) which were adapted from the previous studies. The measurement of OL using 4 indicators adapted from Huber (Schermerhorn et al., 2010) which consist of knowledge acquisition (ACQ), knowledge distribution (DIS), knowledge interpretation (INTR) and organizational memory (MEMO).

The sample size determination in this study refers to the Hair's 10 times rule (Hair et al., 2014). A total of 200 questionnaires were selected which is an adequate number for SEM analysis (Kline, 2016)R. B. (2016. The respondents are employees who work in the clothing industrial sector at the Small Industrial Village in East
Jakarta, Indonesia. The data were collected through a simple random sampling method.

The construct validity test, which was measured using Confirmatory Factor Analysis, was used to validate the data (CFA). To test the multiple relationships between the variables and mediating effect, standardized path coefficient estimates were examined with the critical ratio of tvalue of each path in which the ttable is 1.65 . To test the hypothesis of indirect effect, the Sobel test is used (Hayes, 2018).

\section{RESULTS AND DISCUSSION Results}

Based on confirmatory factor analysis (CFA) after modifications the value of standardized loading factor (SLF) for each instrument ranges between 0.63 and 0.91 and the value of tvalue ranges between 5.63 and 16.93 . These values mean that all instruments are valid with loading factors $>0.5$, and a tvalue $>1.65$. The value of $\mathrm{CR}$ $>0.7, \mathrm{AVE}>0.5$ and Cronbach Alpha $>0.7$ indicate that all instruments are reliable (Hair et al., 2014). The result of CFA (LF) and Construct Reliability (CR), Variance Extracted (VE) and Cronbach Alpha (CA) tests shown in Table 1 indicated that all items are valid and reliable.

Table 1. The Results of Validity and Reliability Test

\begin{tabular}{lcccc}
\hline \multicolumn{1}{c}{ Variable } & Valid items & $\boldsymbol{C R}$ & $\boldsymbol{A V E}$ & $\boldsymbol{C A}$ \\
\hline $\mathrm{OA}$ & 16 & 0.97 & 0.70 & 0.97 \\
$\mathrm{EL}$ & 15 & 0.97 & 0.73 & 0.97 \\
$\mathrm{OL}$ & 15 & 0.96 & 0.62 & 0.96 \\
\hline
\end{tabular}

Source: Output of Lisrel 8.8

The result of fit test is shown in table 2 .

Table 2. The Result of Fit Test

\begin{tabular}{lcl}
\hline \multicolumn{1}{c}{ GOFI } & Value & Decision \\
\hline RMSEA & 0.05 & Good Fit \\
GFI & 0.81 & Good Fit \\
NFI & 0.97 & Good Fit \\
CFI & 0.99 & Good Fit \\
IFI & 0.99 & Good Fit \\
RFI & 0.97 & Good Fit \\
SRMR & 0.03 & Good Fit \\
\hline
\end{tabular}

Thus, it can be confirmed that the model has met the standard of goodness of fit. The overall structural model path diagram between the latent variables, standardized solution and $\mathrm{t}_{\text {value }}$ are shown in Figure 1.

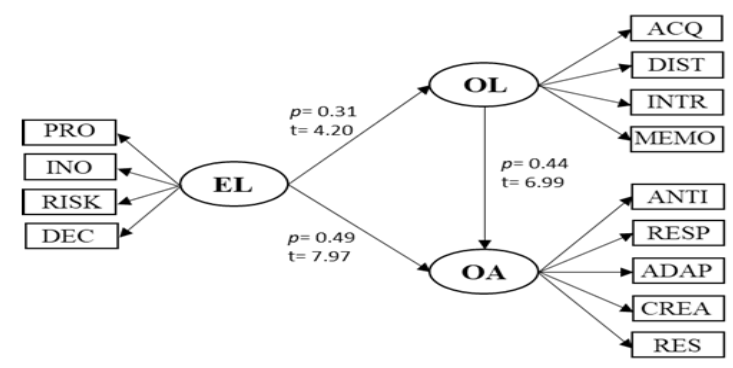

Figure 1. The Structural Equation Model of the Research 
The summary of hypothesis testing results for the direct path is shown in Table 3 .

Table 3. Summary of Hypothesis Testing Result for Direct Effects

\begin{tabular}{cccccc}
\hline Hypothesis & $\begin{array}{c}\text { Path } \\
\text { Coefficient }\end{array}$ & $\mathrm{t}_{\text {value }}$ & $\mathrm{t}_{\text {table }}$ & Significance & Result \\
\hline $\mathrm{H}_{1}: \mathrm{EL} \rightarrow \mathrm{OA}$ & 0.49 & 7.97 & 1.65 & significant & accepted \\
$\mathrm{H}_{2}: \mathrm{OL} \rightarrow \mathrm{OA}$ & 0.44 & 6.99 & 1.65 & significant & accepted \\
$\mathrm{H}_{3}: \mathrm{EL} \rightarrow \mathrm{OL}$ & 0.31 & 4.20 & 1.65 & significant & accepted \\
\hline
\end{tabular}

To test the hypothesis of the indirect effect, the researchers used Sobel test which was carried out by calculating the $\mathrm{z}_{\text {value }}$ based on the path coefficient (unstandardized) and the standard error of estimation. The results of hypothesis testing for the indirect effect shown in Table 4 indicate that $\mathrm{H} 4$ is accepted.

Table 4. Summary of the Hypothesis Test for Indirect Effect

\begin{tabular}{clrrrr}
\hline \multicolumn{1}{c}{ Hypothesis } & $\begin{array}{c}\text { Path } \\
\text { Coefficient }\end{array}$ & $\mathrm{z}_{\text {value }}$ & $\mathrm{z}_{\text {table }}$ & Significance & Result \\
\hline H4: EL $\rightarrow$ OL $\rightarrow$ OA & 0.35 & 3.557 & 1.96 & Significant & Accepted \\
\hline
\end{tabular}

The formula $\mathrm{c}=\mathrm{c}^{\prime}+\mathrm{a} \cdot \mathrm{b}$ (Hayes, 2018) was used to investigate the mediating effect of OL in the relationship between EL and OA, which is illustrated in Figure 2.
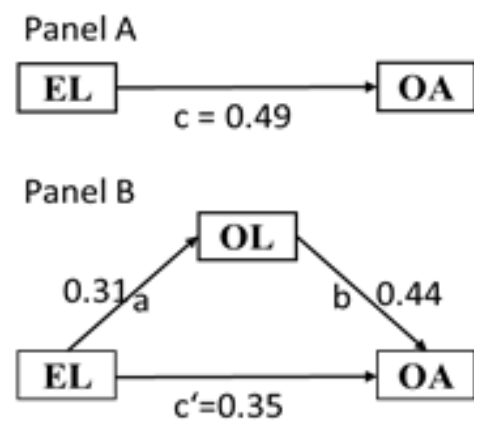

Figure 2. Panel A: Illustration of a direct effect EL on OA. Panel B: Illustration of the indirect effect of EL on OA mediated by OL

The effect of EL on OA before controlled by OL is 0.49(c). The effect of EL on OL is 0.31(a). The effect of OL on OA is $0.44($ b). After mediated by OL, the effect of EL on OL is c' which is obtained using the formula of c' $=$ $c-$ a.b (Hayes, 2018). Therefore $c^{\prime}=0.49-(0.31 \times 0.44)$. It is obtained that the value of c' is 0.35 .

As the value of the effect of EL on OA after controlled decreases from 0.49 (c) to 0.35 (c'), it can be inferred that OL partially mediates the interaction between EL and OA (Hayes \& Rockwood, 2017).

\section{Discussion}

The results of this study provide empirical evidence that EL has a positive effect on OA and OL. These suggest that an improvement in EL will result in an increase in $\mathrm{OA}$ and OL. These findings confirm the theories and previous researches in which the application of EL has had beneficial impacts on OA (de Oliveira et al., 2012; Hosseini et al., 2013; Karimi et al., 2016; Raeisi \&
Amirnejad, 2017; Veiseh et al., 2014) and OL (Golmoradi \& Ardabili, 2016; Imran et al., 2016; Liao et al., 2017; Megheirkouni, 2017). Likewise, the results of this study also indicate that the changes in OL can have a positive effect on the progression of OA. This finding confirms previous studies by several scholars (Imran et al., 2016; Manshadi et al., 2014; Mashkani \& Khodadadi, 2016; Sallitepe et al., 2017).

Given the significant effect of EL on the improvement of OA and OL, SME entrepreneurs should make maximum efforts to improve their EL by increasing their proactiveness and innovativeness. Strengthening proactiveness of leadership should be put as the first priority which means having initiative to anticipate the future outcomes, monitor and enhance the environment, optimize the environment, and encourage action and change without being required to do so (Schmitt et al., 2016). Entrepreneurs must be more proactive in thinking, planning, and implementing and making the required improvements in changes $(\mathrm{Wu}$ \& Wang, 2011) and at the same time have to stimulate employees' proactiveness. Organizations have the need of proactive employees who can independently improve their productivity (Hu et al., 2018), work actively seeking new information and practices to be adaptive to various situations (Yang et al., 2020). Correspondingly, SME entrepreneurs also need to stimulate employees' innovative behavior to maximize entrepreneurial opportunities in the workplace (Bagheri et al., 2020) and remain relevant to today's market environment.

This study also shows that OL partially mediates the interactions between EL and OA. The finding suggests that in order to prompt the impact of EL on OA, it is critical to enhance OL. The main priority in the effort to increase OL is by improving the knowledge acquisition process in the organization. SMEs entrepreneurs must provide employees with the widest possible opportunity to acquire knowledge as one of the most important strategic resources for a company's long-term existence and development (Gatuyu \& Kinyua, 2020). To obtain as much knowledge as possible, SMEs' entrepreneurs should facilitate the employees with knowledge availability and ease of knowledge accessibility through internal and external sources such as job instructions, standard operating procedures (SOPs), trainings, discussions or opportunity to ask questions and communication media, such as internet. so that the employees can learn and develop useful knowledge and experience (Zagoršek et al., 2009). Knowledge must be well distributed or disseminated throughout the organization. It can be carried out through formal mechanisms such as meetings, discussions, crosstraining or informal mechanisms through interactions between individuals in the organization (Schermerhorn et al., 2010).

\section{CONCLUSION}

To succeed and thrive in disruptive environmental changes such as in the ongoing COVID-19 pandemic, Indonesian 
SMEs need to improve their employees' organizational agility by increasing entrepreneurial leadership and organizational learning. Based on the study's findings, some managerial implications are discussed as feedback for SMEs entrepreneurs to solve problems and manage human capital in order to increase organizational agility, in particular. SME entrepreneurs should consider the role of organizational agility in the survival and growth of SMEs, as well as recognizing the factors that could have an effect on organizational agility. Employee perceptions and behaviors toward gaining organizational agility should be strengthened by implementing entrepreneurial leadership and ensuring more successful organizational learning. The findings add theoretical value to the corpus of management science in the areas of organizational behavior and human resource management, especially in the context of small and medium-sized businesses. However, this study has a few limitations. To begin, the analysis concentrated on SMEs in a single geographical region, the garment industry sector in Industrial Village (PIK) in East Jakarta, Indonesia. Future research would be more convincing if it looked at various sectors of SMEs in different areas and regions. Secondly, due to time and budget constraints, the independent variables in this analysis are restricted to entrepreneurial leadership and organizational learning. More independent variables that can potentially impair organizational agility should be studied in future studies.

\section{REFERENCES}

Akkaya, B., \& Celal, M. (2020). The Link between Organizational Agility and Leadership: A Research in Science Parks. Academy of Strategic Management Journal, 19(1), 1-17.

Anca-Loana, M. (2019). A Review of Organizational Agility Concept and Characteristics. The Annals of the University of Oradea, Economic Sciences, Tom, XXVIII(1), 335-341.

Annosi, MC., Martini, A., Brunetta, F., \& Marchegiani, L. (2020). Learning in an agile setting: A multilevel research study on the evolution of organizational routines. Journal of Business Research, 110(May 2017), 554-566.

Bagheri, A., Newman, A., \& Eva, N. (2020). Entrepreneurial leadership of CEOs and employees' innovative behavior in hightechnology new ventures. Journal of Small Business Management, 00(00), 1-23.

Bahrami, MA., Kiani, MM., Montazeralfaraj, R., Zadeh, HF., \& Zadeh, MM. (2016). The Mediating Role of Organizational Learning in the Relationship of Organizational Intelligence and Organizational Agility. Osong Public Health and Research Perspectives, 7(3), 190-196.
Braun, TJ., Hayes, BC., DeMuth, RLF., \& Taran, OA. (2017). The Development, Validation, and Practical Application of an Employee Agility and Resilience Measure to Facilitate Organizational Change. Industrial and Organizational Psychology, 10(04), 702-722.

Chiva, R., Ghauri, P., \& Alegre, J. (2014). Organizational Learning, Innovation and Internationalization: A Complex System Model. British Journal of Management, 25(4), 1-19.

Colquitt, JA., LePine, JA., \& Wesson, MJ. (2017). Organizational Behavior: Improving Performance and Commitment in the Workplace (Fifth). McGraw-Hill Education.

de Oliveira, MA., Valentina, LVOD., \& Possamai, O. (2012). Forecasting project performance considering the influence of leadership style on organizational agility. International Journal of Productivity and Performance Management, 61(6), 653-671.

Do, TT., \& Mai, NK. (2020). Review of Empirical Research on Leadership and Organizational Learning. Journal of Knowledge Management, 24(5), 1201-1220.

Dost, M., Badir, YF., Ali, Z., \& Tariq, A. (2016). The Impact of Intellectual Capital on Innovation Generation and Adoption. Journal of Intellectual Capital, 17(4).

Esmer, Y., \& Dayi, F. (2018). Entrepreneurial Leadership : A Theoretical Framework. Mehmet Akif Ersoy Üniversitesi İtisadi ve İdari Bilimler Fakültesi Dergisi, 4(February). https:// www.researchgate.net/publication/323365395 ENTREPRENEURIAL

Fuller, B., Marler, LE., Hester, K., \& Otondo, RF. (2015). Leader reactions to follower proactive behavior: Giving credit when credit is due. Human Relations, 68(6), 879-898.

Gagel, G. (2018). The Effect of Leadership behaviors on Organizational Agility; A Quantitative Study of 126 U.S - Based Business Units [Colorado State University]. https://mountainscholar. org/bitstream/handle/10217/193105/ Gagel_colostate_0053 A_ 15128 . pdf? sequence $=1 \&$ isAllowed $=\mathrm{y}$

Gagel, G. (2017). The Intersection of Organizational Agility and Transformational Leadership: A Literature Review. Academy of Management Annual Meeting Proceedings, 10895.

Garciá-Vidal, G., Sánchez-Rodríguez, A., PérezCampdesuñer, R., \& Martínez-Vivar, R. (2019). EntrepreneurialLleadership in SMEs: 
Perceptions of Owner-Managers vs. Employees. Management and Production Engineering Review, 10(3), 97-110.

Gatuyu, CM., \& Kinyua, GM. (2020). Role of Knowledge Acquisition on Firm Performance in the Context of Small and Medium Enterprises in Meru County , Kenya. Journal of World Economic Research, 9(1), 27-32.

Golmoradi, R., \& Ardabili, FS. (2016). The Effects of Social Capital and Leadership Styles on Organizational Learning. Procedia - Social and Behavioral Sciences, 230(May), 372-378. http://linkinghub.elsevier.com/retrieve/pii/ S187704281631148X

Gorbiano, MI., \& Iswara, MA. (2020). Jokowi Relaxes Loan Settlements to Help Small Businesses Cope with COVID-19 Effects. The Jakarta Post. https:// www.thejakartapost.com/news/2020/03/25/

Griffin, RW., \& Moorhead, G. (2014). Organizational Behavior: Managing People and Organizations (Eleventh E). South-Western, Cengage Learing.

Hair, JF., C. Black, W., Babin, BJ., \& Anderson, RE. (2014). Multivariate Data Analysis (Seventh). Pearson Education Limited. www.pearsoned. co.uk $\% 0 \mathrm{~A}$

Hayes, AF. (2018). Introduction to Mediation, Moderation, and Conditional Process Analysis: A Regression-Based Approach. The Guilford Press.

Hayes, AF., \& Rockwood, NJ. (2017). RegressionBased Statistical Mediation and Moderation Analysis in Clinical Research: Observations, Recommendations, and Implementation. Behaviour Research and Therapy, 98, 39-57.

Holotiuk, F., Beimborn, D., \& Jentsch, C. (2018). The Determinants and Role of Agility in Digital Organizations. 26th European Conference on Information Systems: Beyond Digitization Facets of Socio-Technical Change, ECIS 2018, $1-17$.

Hosseini, SA., Zare, F., Nematollahi, K., \& Avatefi, E. (2013). The Role of Servant Leadership in Organizational Agility: a Case study in Fars Social Security Organization. European Online Journal of Natural and Social Sciences, 2(3), 2935-2943.

Hu, Y., Wu, X., Zong, Z., Xiao, Y., Maguire, P., Qu, F., Wei, J., \& Wang, D. (2018). Authentic Leadership and Proactive Behavior: The Role of Psychological Capital and Compassion at Work. Frontiers in Psychology, 9(DEC), 1-12.
Imran, MK., Ilyas, M., Aslam, U., \& Ubaid-Ur-Rahman. (2016). Organizational Learning through Transformational Leadership. The Learning Organization, 23(4), 232-248. http://www. emeraldinsight.com/doi/10.1108/TLO-09-20150053

Irawan, A. (2020). Challenges and Opportunities for Small and Medium Enterprises in Eastern Indonesia in Facing the COVID-19 Pandemic and the New Normal Era. TIJAB (The International Journal of Applied Business), 4(2), 79.

Karimi, O., Daraei, M., \& Sepehr, M. (2016). The Effect of Transformational Leadership Style on Components of Organizational Agility in Isfahan University of Technology. International Research Journal of Management Sciences, 4(2), 149-155. http://www.irjmsjournal.com

Kasemsap, K. (2015). Developing a Framework of Human Resource Management, Organizational Learning, Knowledge Management Capability, and Organizational Performance. In P. Ordóñez de Pablos, L. J. Turro, R. D. Tennyson, \& J. Zhao (Eds.), Knowledge Management for Competitive Advantage during Economic Crisis. IGI Global.

Khalid, Z., Madhakomala, R., Purwana, D., and Jakarta, UN. (2020). How Leadership and Organizational Culture Shape Organizational Agility in Indonesian SME's. International Journal of Human Capital Management, 4(2), 49-63.

Kline, RB. (2016). Principles and Practices of Structural Equation Modelling. In T. D. Little (Ed.), Methodology in the social sciences (Fourth Edi). The Guilford Press.

Langer, AM. (2018). Information Technology and Organizational Learning: Managing Behavioral Change in the Digital Age (Third Edit). CRC Press, Taylor \& Francis Group.

Liao, S-H., Chen, C-C., Hu, D-C., Chung, Y-C., \& Liu, C-L. (2017). Assessing the Influence of Leadership Style, Organizational Learning and Organizational Innovation.Leadership \& Organization Development Journal, 38(5), 3-7. http://www.emeraldinsight.com/ doi/10.1108/LODJ-11-2015-0261

Lootah, SE., Mansoor, W., \& Worka, GB. (2020). A Conceptual Exploration of Factors Affecting Agility in Organizations. International Journal of Management (IAEME), 11(July), 165-174,.

Manshadi, MD., Ebrahimi, FP., \& M.Abdi, H. (2014). A Study of the Relationship between Transformational Leadership and Organizational Learning. Europian Journal of Experimental Biology, 4(1), 12--16. 
Mashkani, AJ., \& Khodadadi, M. (2016). The Mediating Role of Organizational Agility in the Relationship between Organizatioal Learning and Organizational Performance. International Business Management, 10(16), 3530-3535.

Matthews, RL., MacCarthy, BL., \& Braziotis, C. (2017). Organisational Learning in SMEs: A process Improvement Perspective. International Journal of Operations and Production Management, 37(7), 970-1006.

Megheirkouni, M. (2017). Leadership Styles and Organizational Learning in UK for Profit and Non Profit Sports Organizations: International Journal of Organizational Analysis, July 2017, $1-16$.

Melián-Alzola, L., Domínguez-Falcón, C., \& MartínSantana, JD. (2020). The Role of the Human dDmension in Organizational Agility: an Empirical Study in Intensive Care Units. Personnel Review, 49(9), 1945-1964.

Menon, S., \& Suresh, M. (2020). Factors Influencing Organizational Agility in Higher Education. Benchmarking. https://doi.org/10.1108/BIJ-042020-0151

Molodchik, M., \& Jordan, C. (2016). Facilitating Organizational Learning in the Russian Business context. The Learning Organization.

Muduli, A. (2016). Exploring the Facilitators and Mediators of Workforce Agility: an Empirical Study. Management Research Review, 39(12), 1567-1586. https://www.researchgate.net/ publication/310799049\%0AExploring

Muduli, A. (2017). Workforce Agility: Examining the Role of Organizational Practices and Psychological Empowerment. Global Business and Organizational Excellence, 36(5), 46-56.

North, K., \& Varvakis, G. (2016). What is a "Dynamic SME." In K. North \& G. Varvakis (Eds.), Competitive Strategies for Small and Medium Enterprises: Increasing Crisis Resilience, Agility and Innovation in Turbulent Times. (pp. 1-18). Springer Cham Heidelberg.

Ozili, P. (2020). Spillover of COVID-19: Impact on the Global Economy. SSRN Electronic Journal, November. https://www.researchgate.net/ publication/340236487 Spillover

Prange, EGK. and C. (2018). Agility, Innovation, and Technological Disruption. In C. Prange \& L. Heracleous (Eds.), Agility. X-How Organizations Thrive in Unpredictable Times (Issue September, pp. 139-151). Cambridge University Press.
Raeisi, N., \&Amirnejad, Q. (2017). Investigating the Effect of Organizational Leadership on Organizational Agility: Mediating Role of Organizational Commitment. International Journal of Economic Perspectives, 11(1), 1154-1168.

Raeymaekers, T. (2010). Review essay: Borders in a "borderless" world. Political Geography, 29(3), 177-181. https://doi.org/10.1016/j. polgeo.2010.01.002

Renko, M. (2018). Entrepreneurial Leadership. In J. Antonakis \& D. V. Day (Eds.), The Nature of Leadership (Third). Sage Publication, Inc.

Saha, N., Gregar, A., \& Sáha, P. (2017). Organizational agility and HRM strategy: Do they really enhance firms ' competitiveness? International Journal of Organizational Leadership, 6.

Sallitepe, H., Otken, AB., \& Beser, HSG. (2017). The Effect of Authentic Leadership on Organizational Learning Providing Organization the Ability to Adapt Quickly and Conveniently to Changing Circumstances. Global Budsiness Research Congress (GBRC), 3(1), 457-471.

Sawaean, FAA., \& Ali, KAM. (2020). The Impact of Entrepreneurial Leadership and Learning Orientation on Organizational Performance of SMEs: The Mediating Role of Innovation Capacity. Management Science Letters, 10(2), 369-380.

Schermerhorn, Jr. et al., JR. (2010). Organizational Behavior (11th ed.). John Wiley \& Sons Inc.

Schermerhorn, JR., G.Hunt, J., Osborn, RN., \& UhlBien, M. (2010). Organizational Behavior (Eleventh E). John Wiley \& Sons, Inc.

Schmitt, A., Den Hartog, DN., \& Belschak, F. D. (2016). Transformational Leadership and Proactive Work Behaviour: A Moderated Mediation Model iIcluding Work Engagement and Job Strain. Journal of Occupational and Organizational Psychology, 89(3), 588-610.

Setili, A. (2014). The Agility Advantage: How to Identify and Act on Opportunities in a Fast-Changing World. Jossey -Bass. http://booksupport.wiley. com

Sharifi, H., \& Zang, Z. (2001). Agile Manufacturing in Practice - Application of a Methodology. International Journal of Operations \& Production Management, 21(5/6), 772-794.

Sherehiy, B., \& Karwowski, W. (2014). The Relationship between Work Organization and Workforce Agility in Small Manufacturing Enterprises. International Journal of Industrial Ergonomics, 44(3), 466-473. 
Steinberg, S. (2015). Make Change Work for You. Piatkus.

Tatachari, S., Manikandan, KS., \& Gunta, S. (2014). A Synthesis of Organizational Learning and Knowledge Management Literatures. In M. A. Chilton \& J. M. Bloodgood (Eds.), Knowledge Management and Competitive Advantage: issue and Potential Solutions. IGI Global.

Triaa, W., Gzara, L., \& Verjus, H. (2016). Organizational Agility Key Factors for Dynamic Business Process Management. 2016 IEEE 18th Conference on Business Informatics (CBI), 64-73.

Veiseh, S., Shiri, A., \& Eghbali, N. (2014). A Study on Ranking the Effects of Transformational Leadership Style on Organizational Agility and Mediating Role of Organizational Creativity. Management Science Letters, 4(9), 2121-2128.

Wageeh, NA. (2016). Organizational Agility: The Key to Organizational Success. International Journal of Business and Management, 11(5), 296.

Wendler, R. (2016). Dimensions of Organizational Agility in the Software and IT Service IndustryInsights from an Empirical Investigation. Communications of the Association for Information Systems, 39(21), 439-482.

Wilantara, RF., \& Susilawati. (2016). Strategi \& Kebijakan Pengembangan UMKM: Upaya
Meningkatkan Daya Saing UMKM Nasional di $\operatorname{Era} M E A$ (R. Indrawan (ed.)). Refika Aditama.

Wu, C., \& Wang, Y. (2011). Understanding Proactive Leadership. Advances in Global Leadership, 6(January 2011), 299-314.

Yang, C., Chen, Y., Zhao, X., \& Hua, N. (2020). Transformational Leadership, Proactive Personality and Service Performance: The Mediating Role of Organizational Embeddedness. International Journal of Contemporary Hospitality Management, 32(1), 267-287.

Yoshino, N., \& Taghizadeh Hesary, F. (2016). Major Challenges Facing Small and Medium-Sized Enterprises in Asia and Solutions for Mitigating Them. In Asian Development Bank Institute Working Papaer Series (Issue 564).

Zagoršek, H., Dimovski, V., \& Škerlavaj, M. (2009). Transactional and Transformational Leadership Impacts on Organizational Learning Linked. Journal Ofor East European Management Studies, 14(2), 144-156.

Zainol, FA., Daud, WNW., Abubakar, LS., Shaari, H., \& Halim, HA. (2018). A Linkage between Entrepreneurial Leadership and SMEs Performance: An Integrated Review. International Journal of Academic Research in Business and Social Sciences, 8(4), 104-118. 